\title{
Journal of Education
}

\section{ISSN Online: 2616-8383}

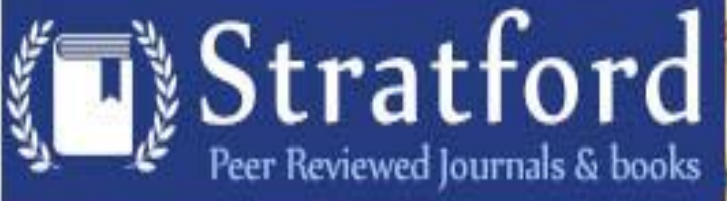

Relationship between students' discipline and academic performance in secondary schools in Rwanda

Sibomana Innocent \& Dr. Hesbon Opiyo Andala 


\title{
Relationship between students' discipline and academic performance in secondary schools in Rwanda
}

\author{
1*Sibomana Innocent \& 2 Dr. Hesbon Opiyo Andala \\ ${ }^{1}$ Post graduate student, Mount Kenya University, Rwanda \\ ${ }^{2}$ Lecturer and research coordinator, school of education, Mount Kenya University, \\ Rwanda
}

*Email of the corresponding Author: sibomanainnocent049@gmail.com

How to cite this article: Innocent, S., \& Andala, H., O. (2021). Relationship between students' discipline and academic performance in secondary schools in Rwanda. Journal of Education, 4(7), 20-37. https://doi.org/10.53819/810181025021

\begin{abstract}
The students' discipline plays a significant role in the improvement of academic performance. However, any lack of students' discipline, significantly affect negatively the level of students' discipline. The purpose of this study therefore was to establish the relationship between students' discipline and academic performance in secondary schools in Rwanda for advanced level studyingFrench-English Kinyarwanda in Rusizi district. The study adopted correlation research design while structured questionnaires, interview guide and desk review were used as data collection instruments. The target population was 283 respondents. The sample size was 166 obtained by the use of Yamane formula. The sample was obtained by the use of simple random and stratified sampling techniques. Questionnaire, interview guide and desk review were used to collect the data. The findings revealed that there is a statistical significant high degree of positive relationship between students' discipline and academic performance. It was revealed that regular class attendance, respect of school rules and regulation and being given punishment among students create a positive change in students' academic performance. The study recommended that the government should design effective policies and discipline guidelines. The head teachers should ensure the suitability of a set of rules and regulations in the least performing schools and there is a need to ensure students punishment management and adequate administration of school rules and regulations. Students should respect and comply with school rules and regulations through punctuality, demand of permission, constant attendance, doing homework at time, respect to teaching staff and school management personnel.
\end{abstract}

Keywords: Students' performance, students' discipline, secondary schools, Rwanda 
Stratford Peer Reviewed Journals and Book Publishing

Journal of Education

Volume 4||Issue 7 ||Page 20-37 ||October||2021|

Email: info@stratfordjournals.org ISSN: 2616-8383

\subsection{Introduction}

The issue of students' discipline in schools is a major concern as highlighted in many national and international education researches and reports. Student discipline referred to behaviour modification for good reason (Zimmerman \& Kitsantas, 2014). In fact, student discipline consists of the establishment of rules, regulations for good conduct and to be sure that guidance are effectively implemented. According to Charles (2013), teaching staff is eager to achieve good conduct and discipline for ensuring good conditions in school settings. A number of researchers such as Dawo and Simatwa (2010) asserted that guidelines related to discipline such as the suspension of students are not able to shift children from bad habits (Ehiane, 2014). A study conducted in USA revealed that the growing problem of indiscipline for students necessitates new policies to be adopted by the government, school administration, teachers, parents and the entire community (Zhao \& Kuo, 2015). Njoroge (2014) noted that a big number of researches carried in USA, elucidated shortcomings that teachers have to overcome.

In Nigeria, Muhammad and Muhammad (2010) noted that a school is where children are socialized and got positive morals values. He added that it is very clear that it is needed to provide guidance to children towards the real ways which is one of the most school tasks and that the provision of curative measures with specificity seems in avoidable describing discipline in secondary schools as a curative measure; postulating that a cursory view is taken purposely in locating possible ways of improving the academic standard, discipline and students' Performance in secondary schools in his bid to respond to the great concerns over the falling standard of education and moral values in our secondary school. It suggested an overall discipline in the entire education sector. Moreover, there is a lack of decision position in implementing school rules and regulations the punishment of students was reported to be administered in an unfair manner that exacerbated the dissatisfaction and anger among students' fraternity which culminated into indiscipline tendencies like attacks, sabotage of school property as well as violence among students (Njoroge \& Nyabuto, 2014). In his study, Haruni (2011) reported the case of Tanzania in respect to discipline of students and he reported that Tanzanian schools had feeble mechanisms of taming students which led to the rise of indiscipline cases among students.

In Rwanda, free secondary education was introduced in 2009 for implementing and attain the education for all (EFA). The adoption of free secondary education increased children's registration. Consequently, the number of teachers and classrooms has been increased with the average teacher ratio of 45.6. A research carried out by Omote et al. (2015) it was demonstrated that the availability of classrooms lead to 50 students for each class. In addition, the aforementioned issue was seen as one of the challenges teachers are facing in their everyday activities by implementing interdisciplinary mechanisms. Students' discipline was seen as a necessary part and indeed the fundamental part of education because of it regulates student's limits their behaviour prevent them from misconduct and clarify punishments if rules are broken. Young teenagers who should be protected from bad influences are exposed to films and other types of media with dangerous contents. Some students end in being attracted by so called stars that are not necessarily good models to identify with (Fawcett, 2013). The attainment of students' academic performance would be achieved through insurance of students in school setting. Therefore, the present study examined students' discipline and academic performance in secondary schools in Rwanda: a case of advanced level studying-French-English Kinyarwanda in Rusizi district.

https://doi.org/10.53819/810181025021 
Stratford Peer Reviewed Journals and Book Publishing

Journal of Education

Volume 4||Issue 7 ||Page 20-37 ||October||2021|

Email: info@stratfordjournals.org ISSN: 2616-8383

\subsection{Statement of the Problem}

Different reports by school inspectors in Rwanda secondary schools particularly Rusizi reveal that students' discipline has deteriorated especially in 6 public secondary schools that teach French subjects, for example, the School inspectors Report (2017-2018), Rusizi district (Charle, 2013). Secondary schools teaching French-English-Kinyarwanda subjects as combination are among the very many schools in Rwanda which lack clear channels of communication, resources and have poor welfare program for students (Rwanda Education Board (REB), 2019). There are allegations that school principals apply disoriented approaches to management of student discipline in public secondary schools teaching French-English-Kinyarwanda subjects as combination which has been attributed to contributing to the high levels of indiscipline among students. Communication between the school administration, parents, teachers and students is either lacking, inadequate or inconsistent The attitudes of those secondary school Head teachers in Rusizi District have not helped much as some of the student indiscipline is cantered on their personality, administrative and leadership style (Rusizi, 2019). Therefore, the study aimed to bridge identified gap where there are many components of students discipline, however, this study was restricted itself to ensuring students' discipline in selected public secondary schools in Rusizi District, analysing the level of performance French-English-Kinyarwanda subjects as combination, and examine how the above discipline is affecting the students' academic performance in public secondary schools in Rusizi District in Rwanda.

\subsection{Objective of the Paper}

The study sought to establish the relationship between students' discipline and academic performance in secondary schools in Rwanda for advanced level studying-French-English Kinyarwanda in Rusizi district.

\subsection{Literature Review}

\subsection{Students' Discipline}

Globally, evidences on students' discipline in secondary schools show that positive and negative enforcement inspire fearfully environment in school settings. In this regards, a study conducted by Omote et al., (2015) contended that student disciple is the action of enforcing and implementing rules and regulations, standards other requirements of the instructions. In fact, this concept is defined in the context of stimulating students to adopt a code of conduct through agreement in secondary schools and it is very important for teachers and students. However, discipline is considered as a cornerstone between those who accept it and those who impose it. Simatwa and Serem (2013) contended that standards have been adopted in which teaching staff, students and non-teaching staff, administrators must respect and obey (Ouma, et al., (2013). discipline was utilized for explaining moral capabilities angered into the human nature. Fawcett, (2013) evidenced that discipline is helpful for students and teachers to comply with crucial actions to enhance their success and decreasing bad behaviour In this regards, students must comply with positive advancement (Dawo \& Simatwa,2010).

\subsection{Regular Attendance}

Ouma, et al. (2013) revealed that teaching staff members could at all period be seen as accountable and willing to people around him or her. The aforementioned situation relied on evidences that 
Stratford Peer Reviewed Journals and Book Publishing

Journal of Education

Volume 4||Issue 7 ||Page 20-37 ||October||2021|

Email: info@stratfordjournals.org ISSN: 2616-8383

students adore their model and reprimand those who they give value and esteem. Teaching staff members who models the class would focus on honest, truth. The penance is the offer of hostile or unfavourable practices on criminal is response to crime. Once rules and regulations have not been effectively enforced, punishment of defiant students becomes necessary as a mechanism to create fear in the potential indiscipline practices

\subsection{Students' Punctuality in Secondary Schools}

Over the years, lateness to school by students of secondary schools has become a recurrent issue. Probably, this was why Busienei (2012) stressed that teachers, parents and others have shown sincere concern about it. In short, recurrent lateness to school by students may be one of the reasons responsible for the falling standards of education all over the world. If lateness to school is allowed to continue, it may have adverse effect on the attainment of the objectives of the Universal Education. However, discipline encompasses punctuality of students in school. It is when learners are present in school and at the right time, that they can benefit optimally from the academic programme. Ehiane (2014) opined that when students are punctual to they are opportune to attend to all school programs and most get full benefits of morning hour lessons such as French-English-Kinyarwanda Languages.

\subsection{Rules and Regulations}

Dawo and Simatwa (2010) evidence that the objective respected with rules and class stimulate a secure working conditions and collaboration. Rules must be strong, researchable and realizable and be the topic to secondary school policies and government regulations. The author evidences that rules in secondary schools were ruled that are associated with teaching and students collaboration an students to students correlation and interaction. It had been revealed that code of conduct in any secondary school can ameliorate the education learning conditions. Ehiane (2014) refers to the reasons and idea that commonly parents and teaching staff must fortify their attitude that are friendly with any expected attitude in students example. It is related to the attitude that was reliable either what leaners need from parents. The study stated up five basics for effective discipline of children including rules and regulations guiding code of conduct and adequate behaviour, misbehaviour, guiding for teaching and learning environment for discipline management like parental- teacher environment. In fact teaching staff, parents and the entire community indicated how children must comply with rules and partners and partner for good practices and it is expected to learn how the family and outside the family. These are familiar with rules, regulations that affect the code of conduct and teaching performance (Busienei, 2012). Furthermore, teaching staff, parents must adopt appropriate models for teaching and learning in order to fortify behavior. Adequate parental involvement such as discipline procedures and rules to increase good practices. There is a need to teach children on how they can meet their expectation, adequately increase interpersonal relationship and assist them to enhance selfdiscipline (Ouma et al., 2013). Parents must have appropriate strategies and approaches in order to overcome challenges of indiscipline cases and misbehaviour. The means of understanding behaviour include disrespect, noncompliance with desired results of parents to their children with positive cooperation between teachers and parents and students (Ehiane, 2014). In fact, there is an expectation to adopt teaching and learning including the encouragement of parent-teacher-students interactions and adequate responses to student endeavor. Therefore, it is very important to seek may strategies by which parents can adopt rules and regulations in order to accept for appropriate

https://doi.org/10.53819/810181025021 
Stratford Peer Reviewed Journals and Book Publishing

Journal of Education

Volume 4||Issue 7 ||Page 20-37 ||October||2021|

Email: info@stratfordjournals.org ISSN: 2616-8383

parental involvement. However, the American Association of Paediatricians and the Canadian Paediatrics Society adopted effective parental disciplinary measures they wrote a report (Innes, 2011).

\subsection{Serving punishment in secondary schools}

Fawcett (2013) there were different kind of penance managed in Tanzanian schools. In Tanzania schools, copious strategies were utilized to follow up students' attitude among others: warning, weeping, scorning, depreciating, name calling, remove of privileges, social isolation and demonition. Innes (2011), the adoption of penance are applied to students who do not respect regulations in secondary schools. However, in many schools, penances were not fair, underserved such as severe dismissing, branding but also mutilation of leaners. They were predictable to apply compliance when learners are under control of school administrators have the same idea but punishment is an explanation of following up disruptive attitude. The author argued that once punishment becomes the logical findings of misconduct, then students are most likely to agree with it without resentment. Teaching staff members could always make students to accomplish the reason why they are being punished. Disruptive students in class were a pertinent issue (Njoroge $\&$ Nyabuto, 2014). This author indicated that the cognitive approach can help to overcome the issue of descriptive behaviour. The intellectual model is related to motivation incentives, interest and objectives. Whether the degree of motivation and interest were large then studying place more readily.

\subsection{Compliance with Value and Goals}

Therefore, persons can change in most cases were permitted or provided on opportunity to administer by selecting their won managers to follow up noice degree and duty achievement. According to Omote et al. (2015) contended that classes with small size had a significant effects on student disciplinary behaviour. The author proposed that secondary schools that were small and with a curriculum that can be easily manipulated can have programs with the intention to adjust indiscipline behaviour. Umutoni (2015) noted that students/ pupils are not allowed to be caned by teachers which has discouraged teachers from confronting the evil of rampant indiscipline in secondary schools. Zhao and Kuo (2015) specified that teaching staff took a back seat in discipline as there were cases of them to be subjected to the court for being punished. A great number of students had to copy with in one class are discouraging the expectation stakeholders interest in educational sector had awareness related to the aforementioned issues. It was evidenced that a class that exceed 35 students become difficult to be managed. It has been argued that secondary schools did not used punishment to leaners non-academic desires.

\subsection{Academic performance in secondary schools}

Previous empirical evidenced on academic performance of students in secondary schools reveal that the performance of students in secondary schools is not the same from country to country and regional to regions according to the subject of the study. However, the analytical work on student academic performance in secondary schools were measured and evaluated in the context of internal examinations. Mocs, homework marks, trimestial exams and continuing assessment tests, and assignment (Way, 2011). A study carried out in Nigeria on the level of academic performance of students in secondary schools demonstrated that with the progress in ensuring school discipline, educational for all and other training in school and national exams, it was

https://doi.org/10.53819/810181025021 
Stratford Peer Reviewed Journals and Book Publishing

Journal of Education

Volume 4||Issue 7 ||Page 20-37 ||October||2021|

Email: info@stratfordjournals.org ISSN: 2616-8383

evidenced by Ehiane (2014) poor performance continue to be apparent among secondary schools in the state. The low level of academic achievement among students in secondary schools in public examination in Oyo state, in the present days render education system impotent to achieve its expected outcomes. However all stakeholders in education sector had criticized the performance of students in secondary schools with special references in English langue and mathematics and other sciences (Zhao \& Kuo, 2015). A survey undertaken in Tanzania on results of four national examinations held in Tanzania from 2003 to 2013 show that the prominent of secondary schools in the top level especially in biology, physics and chemistry were discovered to be very low. The study show the decrease of the level of achievement in the state of Kano in Nigeria (Zimmerman \& Kitsantas, 2014).

\subsection{Relationship between Students' Discipline and Academic Performance in secondary schools}

According to Innes (2011) discipline for students in secondary schools is related to shape, change and adjustment of behaviour where they want to be attentive to the case of the term discipline. The work discipline is considered as the entire functionality of teaching, learning and adopting that encourages children to attain academic performance, self-determination, follow up, improve code of conduct and respecting others. In this regards, discipline is one of the greatest components that stimulates people to enjoy better life in the family, entire society and the country and adjusting comportment. The Paediatric society in Canada, denotes discipline is regarded as system that assist people especially students to be positively integrated in the real life of the world community. For this society the roots of better development and improvement for all students is related to how they behaviour and how they comply to rules and regulations of the school. In addition, adequate and appropriate discipline is linked with how they are taught and guided not non how they are obliged to respect them. In fact, students must be aware of the love and care of parents and teachers in supporting them and these would inspire trustfully in them.

The world of $21^{\text {st }}$ century is characterized by the progression of bad behaviour and indiscipline case in Rwandan secondary schools even after the 1994 genocide against the Tutsi (Muvunyi, 2013). In this regard, Mutie cited by Fawcett (2013) argues that disciplinary problems are the greatest impediment to the academic success of students at secondary schools. Based on a research conducted by similarly Innes (2011) reveals that children to those negative behaviours such as: exciting stories, violence on television. However, indiscipline cases have been observed among students when they are using drug and alcohol, impoliteness, intolerable unwritten countenance of displeasure, intimidation associated students, embargo of educations attacks and offensive conduct (Karega, 2015). Umutoni (2015) revealed that with skilled persons in overcome class may stimulate violence and conflict within a secondary school setting. The researcher argued that using curriculum source is very important. Muhammad and Muhammad (2010) demonstrated the need of anomy in managing teaching and learning process. Secondary schools without design for educational action that had to copy with follow up of children 'attitude toward an opportunity to change their behaviour. 


\subsection{Research Methodology}

The study employed correlation research design in order to find out the extent to which students' discipline can be correlated with academic performance in secondary schools. The target population was 283 respondents. The sample size was 166 obtained by the use of Yamane formula. The sample was obtained by the use of simple random and stratified sampling techniques. Questionnaire, interview guide and desk review were used to collect the data. The data management of this study was maintained by using SPSS version 22 .

\subsection{Research Findings}

The study sought to establish the relationship between students' discipline and academic performance of students in secondary schools in Rusizi district in Rwanda. The study findings were presented in sub sections.

\subsection{Determination of Students' Discipline and Academic Performance in Advanced level studying-French-English Kinyarwanda in Rusizi district.}

The study determined students' discipline under regular attendance, students' punctuality, respect of school rules and regulations, student serve their punishment. The students' discipline was by scores on discipline, frequency, counts and percentages.

Table 1: Students' Scores on Discipline, Frequency Counts and Percentages

\begin{tabular}{lcc}
\hline Students"' scores on discipline & Frequency & Percentage \\
\hline $20-29$ & 1 & 0.5 \\
$30-39$ & 2 & 0.5 \\
$40-49$ & 8 & 4.2 \\
$50-59$ & 18 & 9.3 \\
$60-69$ & 32 & 16.7 \\
$70-79$ & 47 & 24.5 \\
$80-89$ & 50 & 26.1 \\
$90-100$ & 33 & 17.2 \\
Totals & $\mathbf{1 9 1}$ & $\mathbf{1 0 0 . 0}$ \\
\hline
\end{tabular}

Table1 shows a summary of the students" scores. The table shows that the students" scores varied and ranged from 13 to 100 . The table also reveals that a total of $308(37.7 \%)$ of the students scored less than 50 out of the maximum score. These findings imply that $37.7 \%$ of students in secondary schools in Rusizi District, Rwanda were below average. 
Stratford Peer Reviewed Journals and Book Publishing

Journal of Education

Volume 4||Issue 7 ||Page 20-37 ||October||2021|

Email: info@stratfordjournals.org ISSN: 2616-8383

Table 2: Student Regular Attendance

\begin{tabular}{lccccccccc}
\hline Students views & \multicolumn{2}{c}{$\begin{array}{c}\text { Strongly } \\
\text { Agree }\end{array}$} & \multicolumn{2}{c}{ Agree } & \multicolumn{2}{c}{ Disagree } & \multicolumn{2}{c}{$\begin{array}{c}\text { Strongly } \\
\text { disagree }\end{array}$} \\
& $\mathrm{N}$ & $\%$ & $\mathrm{~N}$ & $\%$ & $\mathrm{~N}$ & $\%$ & $\mathrm{~N}$ & $\%$ \\
\hline Best Performing N=(85) & 68 & 80 & 14 & 16.7 & 0 & 0 & 3 & 3.3 \\
Regular presence & 72 & 85 & 28 & 15 & 0 & 0 & 0 & 0 \\
Usually students leave class with permission & 74 & 86.7 & 26 & 13.3 & 0 & 0 & 0 & 0 \\
Active class participation & 74 & 69 & 81.7 & 13 & 15 & 0 & 0 & 3 & 3.3 \\
Ponctuality & & & & & & & & \\
Least Performing N=(106) & 0 & 0 & 21 & 20 & 80 & 75 & 6 & 5 \\
Regular presence & 0 & 0 & 39 & 32 & 72 & 67.5 & 5 & 2.5 \\
Usually students leave class with permission & 0 & & & & & & & & \\
Active class participation & 0 & 0 & 24 & 22.5 & 82 & 77.5 & 0 & 0 \\
& 0 & 0 & 21 & 20 & 85 & 80 & 0 & 0 \\
\hline
\end{tabular}

Student regular attendance is of great importance for academic performance in secondary schools. The study examined how students' student regular attendance in best performing and least performing schools in French-English-Kinyarwanda subjects. Results presented in Table 2 indicated that students have regular presence, $80 \%$ of respondents strongly agreed while 16.7 agreed with the statement. Contrary to the least performing secondary schools, where $20 \%$ agree and only $75 \%$ disagree. Moreover, $85 \%$ of respondents strongly agreed compared to $15.0 \%$ of respondents who agree with the question that usually students leave class with permission. But $30 \%$ of students in least performing schools agree while $67.5 \%$ disagree with the statement. The study show that $86.7 \%$ of respondents strongly agreed that students have active class participation and $33.3 \%$ agree with the statements. For the case of least performing schools, 22.5\% of students agree and $77.5 \%$ disagreed. There is a punctuality, $81.7 \%$ of respondents, strongly agreed that punctuality and $15 \%$ agree with the statement. Contrary to $20 \%$ in least performing schools agree and $80 \%$ who disagree with the statement 
Stratford Peer Reviewed Journals and Book Publishing

Journal of Education

Volume 4||Issue 7 ||Page 20-37 ||October||2021|

Email: info@stratfordjournals.org ISSN: 2616-8383

Table 3: Student Views on their Punctuality

\begin{tabular}{|c|c|c|c|c|c|c|c|c|}
\hline \multirow[t]{2}{*}{ Students views } & \multicolumn{2}{|c|}{$\begin{array}{l}\text { Strongly } \\
\text { Agree }\end{array}$} & \multicolumn{2}{|c|}{ Agree } & \multicolumn{2}{|c|}{ Disagree } & \multicolumn{2}{|c|}{$\begin{array}{l}\text { Disagree } \\
\text { Strongly }\end{array}$} \\
\hline & $\mathbf{N}$ & $\%$ & $\mathbf{N}$ & $\%$ & $\mathbf{N}$ & $\%$ & $\mathbf{N}$ & $\%$ \\
\hline \multicolumn{9}{|l|}{ Best Performing School N=(85) } \\
\hline \multirow[t]{2}{*}{ Ensure that students arrive in class in time } & & & & & & & & \\
\hline & 71 & 83.3 & 14 & 16.7 & 0 & 0 & 0 & 0 \\
\hline Students leave class on time & 68 & 80 & 32 & 20 & 0 & 0 & 0 & 0 \\
\hline Punctuality is also observed by teachers & 77 & 90 & 23 & 10 & 0 & 0 & 0 & 0 \\
\hline Students respected the designed timetable & 75 & 88.3 & 25 & 11.7 & 0 & 0 & 0 & 0 \\
\hline \multicolumn{9}{|l|}{ Least Performing Schools N=(106) } \\
\hline Ensure that students arrive in class in time & 0 & 0 & 80 & 75 & 20 & 25 & 0 & 0 \\
\hline \multirow[t]{2}{*}{ Students leave class on time } & 0 & 0 & 77 & 72.5 & 23 & 27 & 0 & 0 \\
\hline & & & & & & .5 & & \\
\hline Punctuality is also observed by teachers & 0 & 0 & 74 & 70 & 26 & 25 & 2 & 5 \\
\hline Students respected the designed timetable & 0 & 0 & 77 & 72.5 & 26 & 25 & 2 & 2.5 \\
\hline
\end{tabular}

How students views on how they serve their punishment is of great importance for academic performance in secondary schools in French-English-Kinyarwanda subjects. Results presented in Table 3 indicated that students arrive in class in time, $83.3 \%$ of respondents strongly agreed while 16.7 agreed with the statement. Contrary to the least performing secondary schools, where $75 \%$ agree and only $25 \%$ disagree. Moreover, $80.0 \% \%$ of respondents strongly agreed compared to $20.0 \%$ of respondents who agree with the question that students leave class on time. But $72.5 \%$ of students in least performing schools agree while $27 \%$ disagree with the statement. The study show that $90 \%$ of respondents strongly agreed that Punctuality is also observed by teachers and $10 \%$ agree with the statements. For the case of least performing schools, $65 \%$ of students strongly disagree. The Students respected the designed timetable, $88.3 \%$ of respondents, strongly agreed that Students respected the designed timetable and $11.7 \%$ agree with the statement. Contrary to $72.9 \%$ in least performing schools strongly disagree and $25 \%$ who disagree with the statement. 
Stratford Peer Reviewed Journals and Book Publishing

Journal of Education

Volume 4||Issue 7 ||Page 20-37 ||October||2021|

Email: info@stratfordjournals.org ISSN: 2616-8383

Table 4: Students' Views on how abides to prescribed set Rules and Regulations

\begin{tabular}{|c|c|c|c|c|c|c|c|c|}
\hline Students views & $\begin{array}{c}\text { Strongly } \\
\text { Agree }\end{array}$ & & $\underset{\text { e }}{\text { Agre }}$ & & $\begin{array}{l}\text { Disagre } \\
\text { e }\end{array}$ & & $\begin{array}{l}\text { Disagre } \\
\text { Strongly }\end{array}$ & \\
\hline & $\mathrm{N}$ & $\%$ & $\mathrm{~N}$ & $\%$ & $\mathrm{~N}$ & $\%$ & $\mathrm{~N}$ & $\%$ \\
\hline \multicolumn{9}{|l|}{ Best Performing N=85 } \\
\hline $\begin{array}{l}\text { Students do the right thing } \\
\text { at the right time }\end{array}$ & 67 & $\begin{array}{c}78 . \\
3\end{array}$ & 33 & $\begin{array}{c}21 . \\
7\end{array}$ & 0 & 0 & 0 & 0 \\
\hline $\begin{array}{l}\text { Students accepts to let } \\
\text { their mobile at home }\end{array}$ & 62 & $\begin{array}{c}73 . \\
3\end{array}$ & 38 & $\begin{array}{c}26 . \\
7\end{array}$ & 0 & 0 & 0 & 0 \\
\hline $\begin{array}{l}\text { Students attend exam on } \\
\text { time }\end{array}$ & 64 & 75 & 36 & 25 & 0 & 0 & 0 & 0 \\
\hline Students obey teachers & 65 & $\begin{array}{c}76 . \\
7\end{array}$ & 35 & $\begin{array}{c}23 . \\
3\end{array}$ & 0 & 0 & 0 & 0 \\
\hline \multicolumn{9}{|l|}{$\begin{array}{l}\text { Least Performing } \\
\mathrm{N}=(\mathbf{1 0 6})\end{array}$} \\
\hline $\begin{array}{l}\text { Students do the right thing } \\
\text { at the right time }\end{array}$ & 0 & 0 & 0 & 00 & 0 & 0 & 0 & 0 \\
\hline $\begin{array}{l}\text { Students accepts to let } \\
\text { their mobile at home }\end{array}$ & 0 & 0 & 27 & 25 & 79 & 75 & 0 & 0 \\
\hline $\begin{array}{l}\text { Students attend exam on } \\
\text { time }\end{array}$ & 0 & 0 & 11 & 10 & 89 & 65 & 10 & 25 \\
\hline Students obey teachers & 0 & 0 & 9 & 8 & 80 & 75 & 17 & 20 \\
\hline
\end{tabular}

\section{Source: Primary data (2021)}

School rules and regulations are of great importance for academic performance in secondary schools. The study examined how students abide on a set rules and regulations in best performing and least performing schools in French-English-Kinyarwanda subjects. This indicator intended to establish whether school and regulation are respected in French-English-Kinyarwanda classes by asking them if students do the right thing at the right time, $78.3 \%$ of respondents strongly agreed while 21.7 agreed with the statement. Contrary to the least performing secondary schools, all students cast doubt on the respect of a set of their school rules and regulations. Moreover, $73.3 \%$ of respondents strongly agreed compared to $26.7 \%$ of respondents who agree with the question that students accepts to let their mobile. But $75 \%$ of students in least performing schools disagree with the statement. The study show that $75 \%$ of respondents evidenced that students attend exam on time and $25 \%$ agree with the statements. For the case of least performing schools, $65 \%$ of students strongly disagree. This study concurs with the observation of Oduwaye (2011) who argued that head teachers carried out supervision in order to enhance students' academic performance in French-English-Kinyarwanda subjects. OECD (2011) recommends a constant supervision to ensure that students are attending French-English-Kinyarwanda classes in former colonized countries. 
The completion of syllabus is an essence of academic performance, $76.7 \%$ of respondents, strongly agreed that students obey teachers and $23.3 \%$ agree with the statement. Contrary to $20 \%$ in least performing schools strongly disagree and $75 \%$ who disagree with the statement. The researcher held interview with head teachers in order to known the way in which they provide in analysis of school rules and regulations in secondary schools Rusizi District. These habits can hamper good performance of pupils in primary six living examinations. Information from interview with a head teacher says "rules and regulations to this secondary school is adequate owing to our managing styles and consistency in supervisor". The findings from the present research concur with that of Cotton who observes that school regulations may be more clarified and disseminated to parents. The author argued that compliance with school rules and regulations may be achieved via additional policies that can establish suitable and favourable habits to conduct school assignment, test and homework

Table 5: Students Views on how they serve their punishment

\begin{tabular}{|c|c|c|c|c|c|c|c|c|}
\hline \multirow[t]{2}{*}{ Students views } & \multicolumn{2}{|c|}{$\begin{array}{l}\text { Strongly } \\
\text { Agree }\end{array}$} & \multicolumn{2}{|c|}{ Agree } & \multicolumn{2}{|c|}{ Disagree } & \multicolumn{2}{|c|}{$\begin{array}{l}\text { Disagree } \\
\text { Strongly }\end{array}$} \\
\hline & $\mathbf{N}$ & $\%$ & $\mathbf{N}$ & $\%$ & $\mathbf{N}$ & $\%$ & $\mathbf{N}$ & $\%$ \\
\hline \multicolumn{9}{|l|}{ Best Performing School $\mathrm{N}=(\mathbf{8 5})$} \\
\hline $\begin{array}{l}\text { Students accepted to be punished } \\
\text { publically }\end{array}$ & 71 & 83.3 & 29 & 16.7 & 0 & 0 & 0 & 0 \\
\hline Punishment is fair and consistence & 68 & 80 & 32 & 20 & 0 & 0 & 0 & 0 \\
\hline $\begin{array}{l}\text { Defiant students accept to be punished in } \\
\text { classroom }\end{array}$ & 77 & 90 & 23 & 10 & 0 & 0 & 0 & 0 \\
\hline $\begin{array}{l}\text { Classroom has got a disciplinary team } \\
\text { among students }\end{array}$ & 71 & 88.3 & 32 & 11.7 & 0 & 0 & 0 & 0 \\
\hline $\begin{array}{l}\text { Least Performing Schools } \mathbf{N}=(\mathbf{1 0 0}) \\
\text { Students accepted to be punished } \\
\text { publically }\end{array}$ & 0 & 0 & 64 & 75 & 42 & 25 & 0 & 0 \\
\hline Punishment is fair and consistence & 0 & 0 & 77 & 72.5 & 29 & $\begin{array}{l}27 \\
.5\end{array}$ & 0 & 0 \\
\hline $\begin{array}{l}\text { Defiant students accept to be punished in } \\
\text { classroom }\end{array}$ & 0 & 0 & 74 & 70 & 27 & 25 & 5 & 5 \\
\hline $\begin{array}{l}\text { Classroom has got a disciplinary team } \\
\text { among students }\end{array}$ & 0 & 0 & 77 & 72.5 & 27 & 25 & 2 & 2.5 \\
\hline
\end{tabular}

How students serve their punishment is of great importance for academic performance in secondary schools. The examined how students serve on punishment obtained in best performing and least performing schools in French-English-Kinyarwanda subjects. Results indicated in Table 5 that students accepted to be punished publically,83.3\% of respondents strongly agreed while 16.7 agreed with the statement. Contrary to the least performing secondary schools, where $75 \%$ agree and only $25 \%$ disagree. Moreover, $80.0 \% \%$ of respondents strongly agreed compared to 
$20.0 \%$ of respondents who agree with the question that students accepts to let their mobile. But $72.5 \%$ of students in least performing schools agree while $27 \%$ disagree with the statement. The study show that $90 \%$ of respondents strongly agreed that defiant students accept to be punished in classroom and $10 \%$ agree with the statements. For the case of least performing schools, $65 \%$ of students strongly disagree. The classroom has got a disciplinary team among students, $88.3 \%$ of respondents, strongly agreed that students obey teachers and $11.7 \%$ agree with the statement. Contrary to $72.9 \%$ in least performing schools strongly disagree and $25 \%$ who disagree with the statement.

The above findings were supplemented by qualitative responses from heads of schools and discipline masters/mistresses. Through interviews both heads of best and least performing schools were asked to indicate how punishment influences students' academic performance in their respective schools. All 6 heads of schools noted that punishment management helped to maintain school discipline and hence influence students' academic performance. One of the best performing head of school quotes: Discipline your son for in that there is hope, does not be a willing part to his death. Do not withhold discipline from a child: if you punish him with the rod, he will not die. Punish him with the rod and save his soul from death.

Discipline masters/mistresses were asked to indicate how punishment management at school influence students' academic performance. Of 6 discipline masters/mistresses interviewed all agreed that punishment management influence students' academic performance indirectly. One discipline master said that punishment management in the schools make students to follow school rules and regulations and hence put much emphasis on academic matters. As far as positive and negative reinforcement was concerned, negative reinforcement was practiced and positive reinforcement neglected in the school by the teachers. Public punishment and canning of wrong doers was practiced with little deterring practices such as public denunciation of certain behaviour like defiance or by means of public criticism.

\subsection{Academic Performance in Advanced level studying-French-English Kinyarwanda in Rusizi district}

The researcher sought to examine students" performance in French-English-Kinyarwanda Subject in Secondary Schools in Rusizi District- Rwanda. The second objectives established score grades, class participation, and transition rate in the previous five years. Those measurements were assessed to indicate academic performance with both qualitative as well as quantitative examination of the aspects performed. 
Stratford Peer Reviewed Journals and Book Publishing

Journal of Education

Volume 4||Issue 7 ||Page 20-37 ||October||2021|

Email: info@stratfordjournals.org ISSN: 2616-8383

Table 6: Transition rate in secondary schools

\begin{tabular}{lccccccc}
\hline Years & \multicolumn{2}{c}{ Promotion } & \multicolumn{2}{c}{ Repetition } & \multicolumn{2}{c}{ Dropout rate } & Total \\
& $\mathbf{N}$ & $\mathbf{\%}$ & $\mathbf{N}$ & $\mathbf{\%}$ & $\mathbf{N}$ & $\mathbf{\%}$ & Number \\
\hline 2016 & 260 & $79 \%$ & 20 & $7 \%$ & 48 & $14 \%$ & 328 \\
2017 & 280 & 82 & 6 & $2 \%$ & 56 & $16 \%$ & 342 \\
2018 & 306 & $86 \%$ & - & - & 50 & $14 \%$ & 356 \\
2019 & 270 & $78 \%$ & 4 & $1 \%$ & 70 & $21 \%$ & 344 \\
\hline
\end{tabular}

Findings from the Table 6 show that from 2016 to 2019 secondary schools in the context located in Rusizi district recognized promotion at the high level. The table show a trend in repetition rate and school dropout. According to an interview held between the researcher District Education Officer of Rusizi District. He says "school transition rate not low compared to those who enrolled from 2016 to 2019 and the high trends for transition rates was evidenced between 2018 and 2019 decreased for every secondary school depending on the trends of school enrolment. A study conducted by Sariola (2011) did not observe the trend in increasing states. Therefore, results contract with this study by recognizing the increasing trends of school repetition rates from 2016 till 2019.

Table 7: Active Participation in French-English-Kinyarwanda Subject

\begin{tabular}{cccc}
\hline Year & Enrolment & Class participation & $\begin{array}{c}\text { Class participation } \\
\text { rate }\end{array}$ \\
\hline 2016 & 132 & 84 & 63.7 \\
2017 & 136 & 103 & 73.5 \\
2018 & 142 & 116 & 82.0 \\
2019 & 148 & 110 & 83.3 \\
\hline
\end{tabular}

Findings from the Table 7 show that from 2016 to 2019 secondary schools in the context located in Rusizi district recognized school enrolment at the high level. The table show a trend in attending schools and the attendance rates. According to an interview held between the researcher District Education Officer of Rusizi District. He says "school attendance was not low compared to those who enrolled from 2016 to 2019 and the high trends for attendance rates was evidenced between 2018 and 2019 decreased for every secondary school depending on the trends of school enrolment. Results from the present research concur with results observed in a study undertaken by Samani (2011) on impact of strategic planning on students success in secondary schools in Tanzania evidenced that the attendance was higher than $12 \%$ compared to those who remained at schools. In light with the second objective of the study, the researcher concludes that in enrolment in primary school increased and even the attendance rates increased also. Therefore, there is a need to make appropriate strategies to overcome high absenteeism rates. 
Table 8: Scores Grades in National Examination results in French-English-Kinyarwanda Subjects of Sampled Secondary Schools

\begin{tabular}{|c|c|c|c|c|c|c|}
\hline \multirow[t]{2}{*}{ Academic Year } & \multicolumn{6}{|c|}{ GS Gihundwe B } \\
\hline & A & $\mathrm{B}$ & $\mathrm{C}$ & D & $\mathrm{E}$ & $\mathrm{F}$ \\
\hline 2016 & 0.0 & 0.0 & 0.0 & 3.8 & 3.8 & 92.4 \\
\hline 2017 & 0.0 & 0.0 & 4.3 & 13.0 & 21.7 & 61.0 \\
\hline 2018 & 0.0 & 0.0 & 0.0 & 3.3 & 6.6 & 90.1 \\
\hline 2019 & 0.0 & 0.0 & 0.0 & 9.0 & 15.1 & 75.9 \\
\hline \multirow[t]{2}{*}{ Academic Year } & \multicolumn{6}{|c|}{ GS RASANO } \\
\hline & A & $\mathrm{B}$ & $\mathrm{C}$ & $\mathrm{D}$ & $\mathrm{E}$ & $\mathrm{F}$ \\
\hline 2016 & 0.0 & 3.4 & 6.8 & 24.1 & 31.0 & 34.7 \\
\hline 2017 & 3.3 & 3.3 & 10.2 & 16.5 & 30.0 & 36.7 \\
\hline 2018 & 0.0 & 0.0 & 12.0 & 16.0 & 28.0 & 44.0 \\
\hline 2019 & 3.2 & 6.4 & 9.6 & 19.0 & 29.0 & 36.0 \\
\hline \multirow{2}{*}{ Academic Year } & \multicolumn{6}{|c|}{ Sainte Marie reine Nyabitimbo } \\
\hline & A & $\mathrm{B}$ & $\mathrm{C}$ & $\mathrm{D}$ & $\mathrm{E}$ & $\mathrm{F}$ \\
\hline 2016 & 4.1 & 0.0 & 12.5 & 4.1 & 29.2 & 50.1 \\
\hline 2017 & 0.0 & 0.0 & 16.1 & 22.5 & 29.0 & 32.4 \\
\hline 2018 & 0.0 & 0.0 & 15.0 & 10.0 & $30, .0$ & 55.0 \\
\hline 2019 & 0.0 & 4.1 & 8.3 & 16.6 & 25.0 & 46.0 \\
\hline \multirow[t]{2}{*}{ Academic Year } & \multicolumn{6}{|c|}{ GS NYAKABWENDE } \\
\hline & A & $\mathrm{B}$ & $\mathrm{C}$ & $\mathrm{D}$ & $\mathrm{E}$ & $\mathrm{F}$ \\
\hline 2016 & 0.0 & 0.0 & 0.0 & 15.0 & 25.0 & 60.0 \\
\hline 2017 & 0.0 & 4.1 & 8.3 & 16.6 & 29.1 & 41.9 \\
\hline 2018 & 0.0 & 0.0 & 0.0 & 15.7 & 21.0 & 63.3 \\
\hline 2019 & 0.0 & 4.7 & 14.2 & 14.2 & 23.8 & 43.1 \\
\hline \multirow[t]{2}{*}{ Academic Year } & \multicolumn{6}{|c|}{ Gs Butambamo } \\
\hline & A & $\mathrm{B}$ & $\mathrm{C}$ & $\mathrm{D}$ & $\mathrm{E}$ & $\mathrm{F}$ \\
\hline 2016 & 0.0 & 4.5 & 14.2 & 14.2 & 23.8 & 43.3 \\
\hline 2017 & 0.0 & 0.0 & 0.0 & 12.5 & 25.0 & 62.5 \\
\hline 2018 & 0.0 & 7.6 & 10.2 & 15.3 & 17.9 & 49.0 \\
\hline 2019 & 0.0 & 0.0 & 16.6 & 11.1 & 30.5 & 41.8 \\
\hline \multirow[t]{2}{*}{ Academic Year } & \multicolumn{6}{|c|}{ GS Sainte Marie Reine Mibirizi } \\
\hline & A & B & $\mathrm{C}$ & $\mathrm{D}$ & $\mathrm{E}$ & $\mathrm{F}$ \\
\hline 2016 & 6.5 & 12.9 & 12.9 & 22.5 & 22.5 & 22.7 \\
\hline 2017 & 3.5 & 15.3 & 15.3 & 11.5 & 19.2 & 50.3 \\
\hline 2018 & 0.0 & 20.6 & 10.3 & 17.2 & 17.2 & 34.7 \\
\hline 2019 & 3.3 & 10.0 & 16.6 & 20.0 & 10.0 & 40.1 \\
\hline
\end{tabular}

Source: Rusizi District (2021)

According to information obtained in six Secondary schools teaching French-EnglishKinyarwanda subjects, it was felt that there is a low level of grade obtained in national examination as summarized in Table 8. The research has categorized results into two groups: Low grade (D,E,F) 
and high grade(A,B,C). Results from GS gihundwe indicated that in 2016 more than $92.4 \%$ students obtained F, 61\% in 2017, 90\% in 2018 and 75.9\% in 2019. Results from GS Rasano in 2016 near $34.7 \%$ obtained grade F, 36.7\%, in $2017,44 . \%$ in 2018 , and $36 \%$ in 2019 .Results from saint marie reine Nyabitimbo, in 2016 more than 50.1\% obtained grade F, 32.4 in 2017, 55\% in 2018 and $46 \%$ in 2019 . The researcher concludes that the above secondary schools obtained low grade(performance in national examination).

Contrary to the following secondary schools that attempted to obtained some grade (ABC). In this regards, Gs Nyakabwende, in 2016 more $60 \%$, in 2017 was $4.1 \%$ of obtained grade B, in 2018 was $63.3 \%$ and in 2019 was $4.7 \%$ obtained grade B. Results from Butambamo indicated that $4.5 \%$ students obtained B in 2016, in 2017 was $62.5 \%$ obtained F, in 2018, 7.6\% obtained B and 2019, 16.6\% obtained C. Finally at Sainte Marie Reine Mibirizi in 2016, 6.5\% had A, in 2017 was $3.5 \%$ for A, in 2018 was $20.6 \%$ for B while in 2019 was $3.3 \%$ for A. The researcher held interview with head teachers in order to known the way in which they provide in analysis of the previous national examination results of sampled secondary schools in Rusizi District since 2016. This has been stimulated by the adoption of discipline management strategies in year 2016 which led to improving performance (Ministry of education,2019).

\subsection{Relationship between Students' Discipline and Academic Performance in secondary schools in Rwanda}

The correlation between students "discipline and students' performance French-EnglishKinyarwanda Subjects was established by correlating each of the students' discipline i.e. regular attendance, respect rules and regulations, serve to punishment, punctuality and students" academic performance in French-English-Kinyarwanda subjects in Rusizi District.

Table 9: Correlations between Students Discipline and Academic Performance in FrenchEnglish-Kinyarwanda Subjects in Rusizi District

Transition rate

Score grades

obtained Participation

\begin{tabular}{llccc}
\hline Regular attendance & Pearson Correlation & $.843^{* *}$ & $.871^{* * *}$ & $.957^{* *}$ \\
& Sig.(2-tailed) & .000 & .000 & .000 \\
& $\mathrm{~N}$ & 191 & 191 & 191 \\
Respect of Rules and & Pearson Correlation & $.852^{* *}$ & $.873^{* *}$ & $.949^{* *}$ \\
regulations & Sig.(2-tailed) & .000 & .000 & .000 \\
& $\mathrm{~N}$ & 191 & 191 & 191 \\
Students' serve to & Pearson Correlation & $.962^{* *}$ & $.934^{* *}$ & $.863^{* *}$ \\
punishment & Sig.(2-tailed) & .000 & .000 & .000 \\
& \multicolumn{1}{c}{$\mathrm{N}$} & 191 & 191 & 191 \\
\hline
\end{tabular}

Results presented in Table 9 indicates the correlation between regular attendance and score grades obtained in French-English-Kinyarwanda produced Pearson correlation coefficient $r=0.843$ 
between score grades obtained in French. It was 0.871 between Participation in French-EnglishKinyarwanda Subject and 957 between transition rate. This shows that the relationships were all positive and statistically significant. Each of these elements significantly increase academic performance of the students when they are improved.

Furthermore, the study findings evidenced that the correlation between respect of rules and regulations and high score grades was $0.852^{* *}$, the correlation between respect of rules and regulations and participation in French-English-Kinyarwanda Subject was $873^{* *}$ and the correlation between respect of rules and regulations and transition rate was $.949 * *$. Moreover, Students' serve to punishment is correlated with high score grades $.962 * *$, it has a significant relationship with participation in French-English-Kinyarwanda subject at $.934^{* *}$ and with transition rate was at $.863^{* *}$.

Results are in line with the research of Buseienei (2012) who found that the use of punishment in schools instils discipline and punish those who do not respect schools guidance. This allows learning to occur while role modelling gives students a good example to imitate with appropriate class control strategies like providing rules and improvement of academic performance (Mussa, 2015). Students' discipline was correlated with students' academic performance. The finding shows that the correlation between discipline management strategies and students' academic performance was strong, positive and statistically significant. For every increase in students discipline, the students" academic performance also improved significantly.

\subsection{Summary of findings and Conclusion}

The correlation between students' discipline and academic performance in Rusizi District was established by correlating each of the students i.e. regular attendance, punctuality in FrenchEnglish-Kinyarwanda Subject, respect to a set of rules and regulations, students serve to punishment in French-English-Kinyarwanda subjects and academic performance in FrenchEnglish-Kinyarwanda subjects in Rusizi District. Results presented indicated the correlation between regular attendance and score grades obtained in French-English-Kinyarwanda produced Pearson correlation coefficient of $0.843(\mathrm{r}=0.843)$ between score grades obtained. It was 0.871 between Participation in French-English-Kinyarwanda Subject and 957 between transition rates. This shows that the relationships were all positive and statistically significant. Each of these elements significantly increases academic performance of the students when they are improved. Furthermore, the study findings evidenced that the correlation between respect of rules and regulations and high score grades was $0.852 * *$, the correlation between respect of rules and regulations and participation was $873^{* *}$ and the correlation between respect of rules and regulations and transition rate was $.949^{* *}$. Moreover, Students' serve to punishment is correlated with high score grades $.962 * *$, it has a significant relationship with participation at $.934 * *$ and with transition rate was at $.863^{* *}$. The study concluded that there is a correlation between indiscipline of students' and low level of academic performance in Rusizi District. 
Stratford Peer Reviewed Journals and Book Publishing

Journal of Education

Volume 4||Issue 7 ||Page 20-37 ||October||2021|

Email: info@stratfordjournals.org ISSN: 2616-8383

\subsection{Recommendations}

Based on the study findings, the following recommendations were made;

1. The study recommended that school head teachers should ensure the suitability of a set of rules and regulations in the least performing schools and there is a need to ensure students punishment management and adequate administration of school rules and regulations.

2. The Government of Rwanda should design effective policies tailored towards empowering its education agencies to collaboratively effect the school discipline guidelines throughout the education system. If these policies are fully implemented, improved discipline would enhance student performance in secondary schools.

3. Head teachers/school principals should help their teachers in understanding that discipline management is key for success and therefore set aside budget for trainings as well as facilitations for good practices.

4. Students should respect and comply with school rules and regulations through punctuality, demand of permission, constant attendance, doing homework at time, respect to teaching staff and school management personnel.

\section{Acknowledgments}

I am very grateful to my supervisor Dr Andala H.O $(\mathrm{PhD})$ for the wise guidance and encouragement as my supervisors, while carrying out this project. I must also take record of my appreciation to Mount Kenya University. My appreciation goes to my wife for her incredible patience and support. Last but not least, are my relatives and co-workers to whom I extent my gratitude for their moral encouragement. Much special thanks go to all my friends and classmates for their supportive and their strong friendship in my studies.

\section{REFERENCES}

Charles, K. O. (2013). The impact of students' socioeconomic background on Academic performance in universities, a case study in Kisi University College. American international journal of social science, 2(2)12-21.

Dawo, A. J. -I., \& Simatwa, E. M. W. (2010). Opportunities and challenges for mixed day secondary school head teachers in promoting girl-child education in Kenya: A case study of Kisumu Municipality. Educational Research and Reviews, 5(12), 730-741. Retrieved from http://www.academicjournals.org/err [Accessed on 10/07/2018]

Ehiane, O. S. (2014). Discipline and academic performance (a study of selected secondary schools in Lagos, Nigeria). International Journal of Academic Research in Progressive Education and Development, 3(1), $181 \quad-\quad 194 . \quad$ Retrieved from http:/hrmars.com/hrmars_papers/Discipline_and_Academic_Performance.pdf.

Fawcett, A. L. (2013). Principles of assessment and outcome measurement for occupational therapists and physiotherapists: Theory, skills and application. Retrieved from http://books.google.com [ Accessed on 30/06/2018]

https://doi.org/10.53819/810181025021 
Karega L.N. (2015). Institutional factors influencing motivation among primary Kenya, a case study of Bungoma County. International research journals 3(2),

Muhammad, F.J \&Muhammad, A.K. (2010). Impact of parental socioeconomic status on students' educational achievement at secondary schools of district Malir, Karachi, Middle East journal of scientific research, Vol. 6. No. 6

Njoroge, P. M., \& Nyabuto, A. N. (2014). Discipline as a factor in academic performance in Kenya. Journal of Educational and Social Research. 4 (1), 289-307. doi:10.5901/jesr.2014.v4n1p289. https://doi.org/10.5901/jesr.2014.v4n1p289

Omote, M. J., Thinguri, R.W., and Moenga, M. E. (2015). A critical analysis of acts of student indiscipline and management strategies employed by school authorities in public high schools in Kenya. International Journal of Education and Research, 3(12), 1-10.

Ouma, M. O., Simatwa, E. W., and Serem, T. D. K. (2013). Management of pupil discipline in Kenya: A case study of Kisumu Municipality. Educational Research,4(5), 374-386.

Zhao, R., \& Kuo, Y. L. (2015). The role of self-discipline in predicting Performance for 10th graders. International Journal of Intelligent Technologies and Applied Statistics,8(1), 6170. DOI: 10.6148/IJITAS.2015.0801.05

Zimmerman, B. J., \& Kitsantas, A. (2014). Comparing students' self-discipline and self-regulation measures and their prediction of academic Performance. Contemporary Educational Psychology, 39(2), 145 -155. Retrieved from http://www.sciencedirect.com [Accessed on 23/07/2018]. https://doi.org/10.1016/j.cedpsych.2014.03.004 